\title{
EVALUATION OF IMPACT PROPERTIES OF BASALT AND JUTE FIBER REINFORCED IN POLYMER COMPOSITES
}

\author{
Goudar Santosh Gangappa (M.Tech Scholar) \\ Department of Computer Aided Engineering \\ Visvesvaraya Technological University, CPGS, \\ Bangalore Region, Chikkaballapura, \\ Karnataka, India
}

\begin{abstract}
In recent year's composite materials are playing prominent role in various application and also these materials have a better capability of improving basic human living standards, these materials are forming a symbol of progress in new technology and these materials are considered as pillar of modern science and technology. Basalt fiber is a relative new comer to fiber reinforced polymer and structural composites. Jute is a natural fiber. In this project both basalt and jute fibers are considered. This work investigates impact properties of composites prepared by using eight plies of basalt fiber and also basalt and jute (hybrid) in polyester matrix. The composite laminates were prepared using compression molding with varying thickness by taking into account $2 \mathrm{~mm}$ and $3 \mathrm{~mm}$ basalt fiber, basalt \& jute fiber (hybrid) in polyester matrix. The specimens were prepared and fabricated according to ASTM standards for polymer composites. The results of varying thickness were studied based on the impact properties for basalt fiber, basalt \& jute fiber (hybrid) and compatibility is achieved.
\end{abstract}

Keywords -- Basalt fiber, Polyester resin, FRP, ASTM Standards.

\section{INTRODUCTION}

A composite material cab be defined as a combination of two or more materials that results in better properties than those of the individual component used alone. In contrast to metallic alloys each material retains its separate chemical, physical and mechanical properties. The two constituents are a reinforcement and a matrix. The main advantages of composite materials are their high strength and stiffness combined with low density when compared with low density, when

\author{
Sripad Kulkarni S (M.E Scholar) \\ Department of Mechanical Engineering \\ University Visvesvaraya College of Engineering \\ Bangalore, Karnataka, India
}

compared with bulk materials, allowing for a weight reduction on the finished part.

Composite substances are engineering materials made of two or more mixtures of fabric material with expressive chemical or physical properties that remain separate and distinct within the finished material at microscopic level. All composites will preserve their identity and do not dissolve or merge completely with one another. The composite material should be created to obtain properties that cannot be carried by any single component. Natural fiber reinforced polymer matrix composites can be found in sports, goods, automotive and aircraft applications. Polymer matrix composites are typically having a good property such as advanced rigidity low weight and excessive strength. The polymer composites have lesser strength and stiffness than the ceramic composites and metal matrix composites. The polymer matrix composites are growing rapidly as the preparation of PMC is simple and no longer requires high pressure and temperature and has become more popular in comparison with other composites such as MMCs and CMCs for structural applications. Despite the tremendous advantages and disadvantages composites have over metals in application requiring high strength, stiffness and low weight in applications where impact by foreign objects is a desired consideration the advantages inherent in composites are overshadowed by their poor response to impact loading. [5]

The current composite material project is discussed by considering the literature review. The current literature review concentrates on the behavior of different composite material on impact properties. The literature review can be discussed below:

1. Nayan Patel et al (2017) studied investigations on mechanical strength of hybrid basalt glass polyester composites, this study was focused on tensile, flexural and impact properties from these studies it was concluded that the effect of stacking 


\section{International Journal of Engineering Applied Sciences and Technology, 2019 \\ Vol. 4, Issue 4, ISSN No. 2455-2143, Pages 350-354 \\ Published Online August 2019 in IJEAST (http://www.ijeast.com)}

sequence on impact, flexural and impact properties of basalt glass polyester hybrid composites was investigated in this study. To get maximum impact strength for basalt-glass hybrid polyester composites stacking sequence gives maximum impact strength.

2. K Arun Prasath et al (2013) studied the mechanical behavior of woven fabric jute fiber reinforced polymer hybrid composites from this study describes the basalt fiber and jute fiber reinforced hybrid composites with polyester resin with stacking sequence from this studied it was concluded that composites alone with polyester was superior to jute fiber reinforced hybrid composites.

3. M. Vijay Kumar et al (2017) studied the comparison study of basalt fiber and steel fiber as additives and concrete in this paper the fiber reinforced concrete plays a very prominent role in structural engineering composites applications from this paper it was concluded that when the basalt fiber is compared with the steel fiber deforms is having higher strength values than the later.

4. Namasivayam Navaranjan et al (2017) studied the impact strength of natural fiber composites measured by different test methods after reviewing the literature the impact resistance of jute fiber composites that were measured using different test methods has been compared and discussed. From this paper it was concluded thatat most composites are brittle in nature they can absorb energy during elastic deformation and each composite can have similar damage mechanisms.

\section{Summary of literature review:}

From the literature review there was a brief introduction on natural fiber and its importance in the current scenario of composites and also pretreatment for natural fiber and also highlighted the potential use of natural fiber reinforced composites. Also the literature survey revealed that to get a maximum strength the variation in stacking sequence was the must.

\section{MATERIALS}

\section{A. Material Used \\ 1. Basalt fiber}

Basalt fiber is a natural fibre made from highly fine basalt filaments or in other words, plagioclase, pyroxene and olivine minerals. It is like fiberglass, which has physico- mechanical properties rather than fiberglass, but is essentially less expensive than carbon fiber (CF). It is used as a flameresistant material in automotive and aviation companies. Basalt fiber is produced from a carefully selected quarry source using a solitary material and pulverized basalt [6].

\section{Jute fiber}

Jute is one of the most moderate natural fibres in the world and second only to cotton in the quantity and variety of usage. Jute fibres are mainly made from cellulose and lignin from plant materials. It falls into the bast fiber class alongside kenaf, hemp, ramie and so on. The modern term jute is a jute raw and jute is also brilliant fiber for its high value and shading.

\section{Polyester Resin}

Thermoset matrices are unsaturated polyester, offering an attractive combination of low cost, sensitive features and easy handling. A polyester resin is unsaturated and a (reactive) polyester solid in a polymerizable monomer is broken down. Unsaturated polyesters are long chain coordinate polymers contain different carbon twofold securities. They are produced by a development reaction between a glycol and an unsaturated (malic or fumaric) dibasic destructive. The polymerizable monomer, styrene that aalso contains twofold carbon bonds, acts as a crossinterface by spreading over neighboruring polyester particles in their instauration centers [7].

\section{METHODOLOGY}

The methodology used in current project work is shown in the below flow chart:

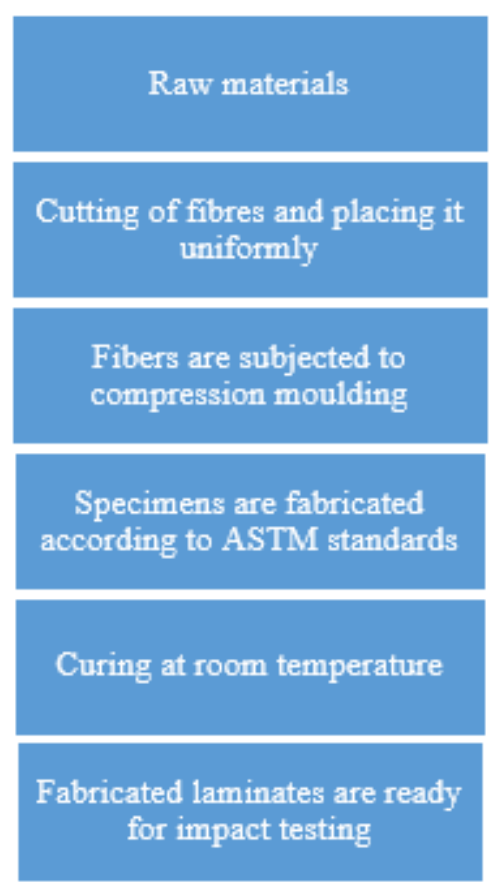

Fig. 1. Flow chart of methodology

The objectives of this project are to determine impact properties of hybrid composites based on 


\section{International Journal of Engineering Applied Sciences and Technology, 2019 \\ Vol. 4, Issue 4, ISSN No. 2455-2143, Pages 350-354 \\ Published Online August 2019 in IJEAST (http://www.ijeast.com)}

thickness as a parameter during the fabrication of hybrid composites.

$$
\text { IV. EXPERIMENTATION }
$$

The standard specimen of $8 \mathrm{~B} 2,8 \mathrm{~B} 3,4 \mathrm{~B} 4 \mathrm{~J} 2$ and 4B4J3 are subjected to impact test as per ASTM standards. Results were tabulated and compared on the basis of fiber reinforcement in order to evaluate the variation in strength of composite laminates.

The manufacture of basalt fiberr composite and the hybrid of basalt jute fibre composite laminate with polyester resin is carried out in this project. The laminates were prepared using a hand layup technique and a closed molding technique. In the current work we tried to vary the thickness for both laminate i.e. $2 \mathrm{~mm}$ and $3 \mathrm{~mm}$ for basalt and hybrid basalt/jute composite laminate respectively. The 8 ply basalt and 4 ply basalt/4 ply jute hybrid are fabricated as per the below given figure:

\begin{tabular}{|l|}
\hline Basalt \\
\hline Basalt \\
\hline Basait \\
\hline Basait \\
\hline Basalt \\
\hline Basait \\
\hline Basalt \\
\hline Basalt \\
\hline
\end{tabular}

\begin{tabular}{|l|}
\hline Basalt \\
\hline Jute \\
\hline Basait \\
\hline Jute \\
\hline Jute \\
\hline Basait \\
\hline Jute \\
\hline Basalt \\
\hline
\end{tabular}

Fig. 2. Fabricated basalt and jute hybrid composites

Both the basalt and the jute fabrics were cut into the required length and width of $300 \mathrm{~mm}$. The polyester resin is mixed with accelerator and catalyst. The hand layup technique is used to prepare laminate as shown figure 3 . To maintain the thickness of the laminate spacers are used of thickness $2 \mathrm{~mm}$ and $3 \mathrm{~mm}$ and these fibres were subjected to compression molding and the temperature of the die is set to around $80^{\circ} \mathrm{C}$. The curing time for removing the laminates from the mould is 30 minutes. The load applied on the die is 2000 psi. The below figures shows the hand layup process and fabricated laminates.

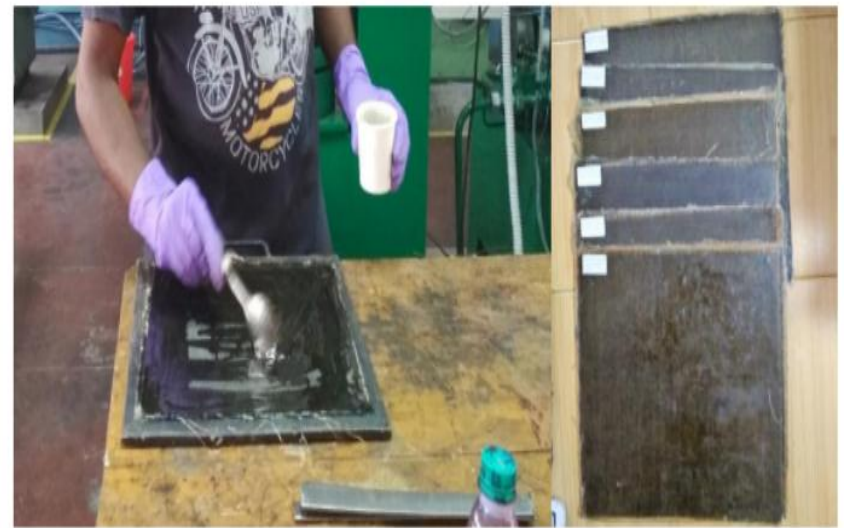

Fig. 3. Hand layup of composites

\section{SPECIMEN PREPARATION}

Once the composite laminates have been prepared according to ASTM standards for impact test, the cutting is done by using saw cutting machine. The below figure shows the specimen preparation using band saw cutting machine.

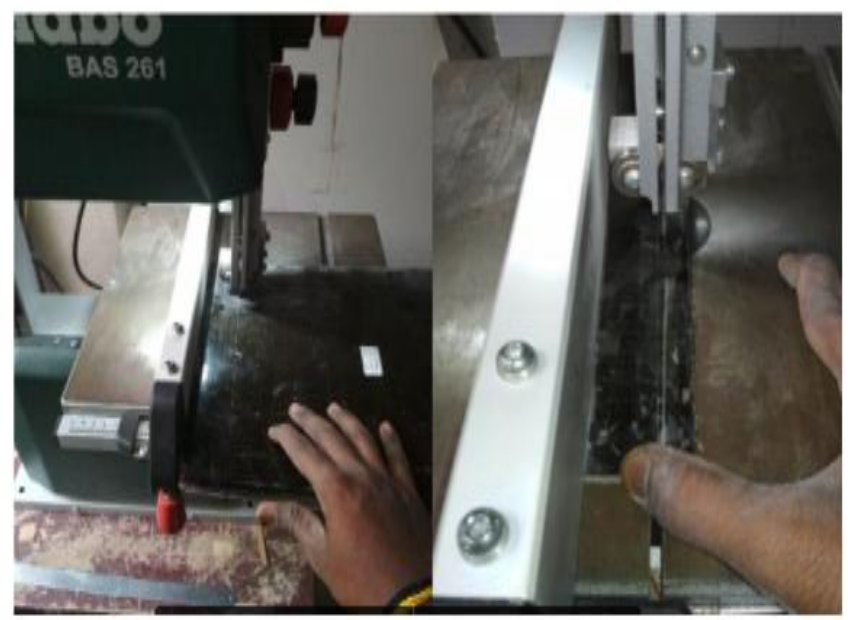

Fig. 4. Specimen preparation using band saw cutting machine

The impact test specimen was prepared according to the ASTM D790 standards with the standard dimensions of $12 \mathrm{~mm} \times 60 \mathrm{~mm} \times \mathrm{t} \mathrm{mm}$. After the preparation of specimens as per standards, the specimens were subjected to check for impact properties on a computerized impact testing machine of make international equipment's Mumbai. The computerized impact tester machine is shown in the below figure 5 . 


\section{International Journal of Engineering Applied Sciences and Technology, 2019 \\ Vol. 4, Issue 4, ISSN No. 2455-2143, Pages 350-354 \\ Published Online August 2019 in IJEAST (http://www.ijeast.com)}

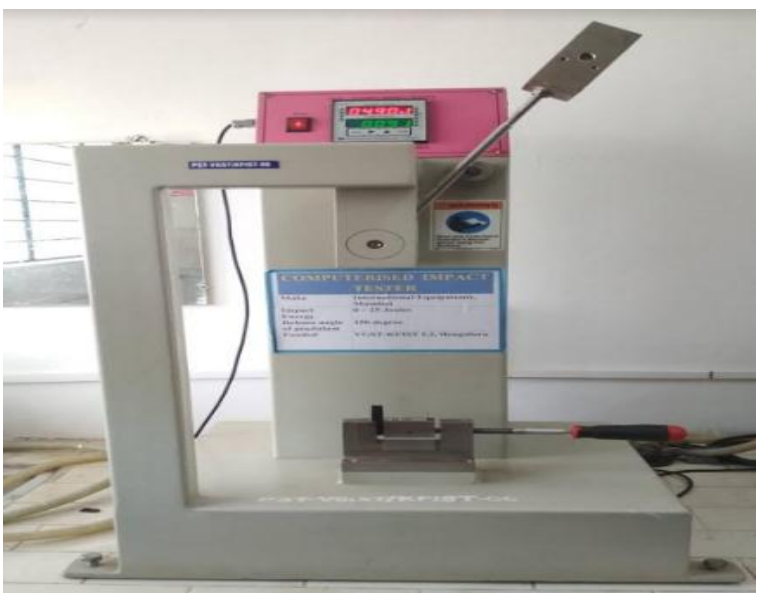

Fig. 5. Computerized impact testing machine

A pendulum type single blow impact test in which the specimen usually notched is fixed at one end and free at other end. The specimen is broken by a falling pendulum which is a measure of impact strength. The obtained digital reading of impact test was noted by computerized impact testing machine.

\section{RESULTS AND DISCUSSIONS}

The results obtained from the computerized impact testing machine are discussed below the tabular column of the impact properties are shown below:

Table. 1 Impact properties of hybrid composites.

\begin{tabular}{|c|c|c|c|c|c|c|c|}
\hline $\begin{array}{l}S \\
r\end{array}$ & $\begin{array}{l}\text { Lami } \\
\text { nate }\end{array}$ & $\begin{array}{l}\text { Stac } \\
\text { king } \\
\text { seq } \\
\text { uen } \\
\text { ce }\end{array}$ & $\begin{array}{l}\text { Wid } \\
\text { th } \\
\mathrm{mm}\end{array}$ & $\begin{array}{l}\text { Len } \\
\text { gth } \\
\text { mm }\end{array}$ & $\begin{array}{l}\text { Thick } \\
\text { ness } \\
\text { mm }\end{array}$ & $\begin{array}{l}\text { Imp } \\
\text { act } \\
\text { Ener } \\
\text { gy } \\
\text { in } \mathrm{J}\end{array}$ & $\begin{array}{l}\text { Average } \\
\text { impact } \\
\text { energy } \\
\text { in J }\end{array}$ \\
\hline 1 & $\begin{array}{l}2 \mathrm{~mm} \\
\text { basalt }\end{array}$ & $8 B 2$ & $\begin{array}{l}11.5 \\
3\end{array}$ & 61.0 & 2.37 & 3.00 & 3.95 \\
\hline 2 & $\begin{array}{l}2 \mathrm{~mm} \\
\text { basalt }\end{array}$ & $8 \mathrm{~B} 2$ & $\begin{array}{l}12.3 \\
4\end{array}$ & $\begin{array}{l}59.1 \\
4\end{array}$ & 2.45 & 4.9 & 3.95 \\
\hline 3 & $\begin{array}{l}3 \mathrm{~mm} \\
\text { basalt }\end{array}$ & $8 B 3$ & $\begin{array}{l}11.7 \\
2 \\
\end{array}$ & $\begin{array}{l}61.1 \\
2 \\
\end{array}$ & 2.75 & 4.4 & 3.95 \\
\hline 4 & $\begin{array}{l}3 \mathrm{~mm} \\
\text { basalt }\end{array}$ & $8 B 3$ & 9.71 & $\begin{array}{l}59.5 \\
2 \\
\end{array}$ & 2.77 & 3.5 & 3.95 \\
\hline 5 & $\begin{array}{l}2 \mathrm{~mm} \\
\mathrm{~B}+\mathrm{J}\end{array}$ & $\begin{array}{l}\text { 4B44 } \\
\mathrm{J} 2\end{array}$ & $\begin{array}{l}12.2 \\
0\end{array}$ & $\begin{array}{l}58.9 \\
7\end{array}$ & 2.10 & 1.3 & 1.7 \\
\hline 6 & $\begin{array}{l}2 \mathrm{~mm} \\
\mathrm{~B}+\mathrm{J}\end{array}$ & $\begin{array}{l}\text { 4B44 } \\
\mathrm{J} 2\end{array}$ & $\begin{array}{l}12.2 \\
1\end{array}$ & $\begin{array}{l}61.5 \\
5 \\
\end{array}$ & 2.15 & 2.1 & 1.7 \\
\hline 7 & $\begin{array}{l}3 \mathrm{~mm} \\
\mathrm{~B}+\mathrm{J}\end{array}$ & $\begin{array}{l}\text { 4B44 } \\
\mathrm{J} 3\end{array}$ & $\begin{array}{l}11.8 \\
1\end{array}$ & $\begin{array}{l}61.2 \\
0 \\
\end{array}$ & 4.01 & 4.20 & 3.8 \\
\hline 8 & $\begin{array}{l}3 \mathrm{~mm} \\
\mathrm{~B}+\mathrm{J}\end{array}$ & $\begin{array}{l}\text { 4B44 } \\
\mathrm{J} 3\end{array}$ & $\begin{array}{l}11.0 \\
1\end{array}$ & $\begin{array}{l}59.5 \\
4\end{array}$ & 4.04 & 3.40 & 3.8 \\
\hline
\end{tabular}

The variation in impact energy shown in the table can also be represented in graph as it is shown below, the graph is a plot of stacking sequence versus impact properties.

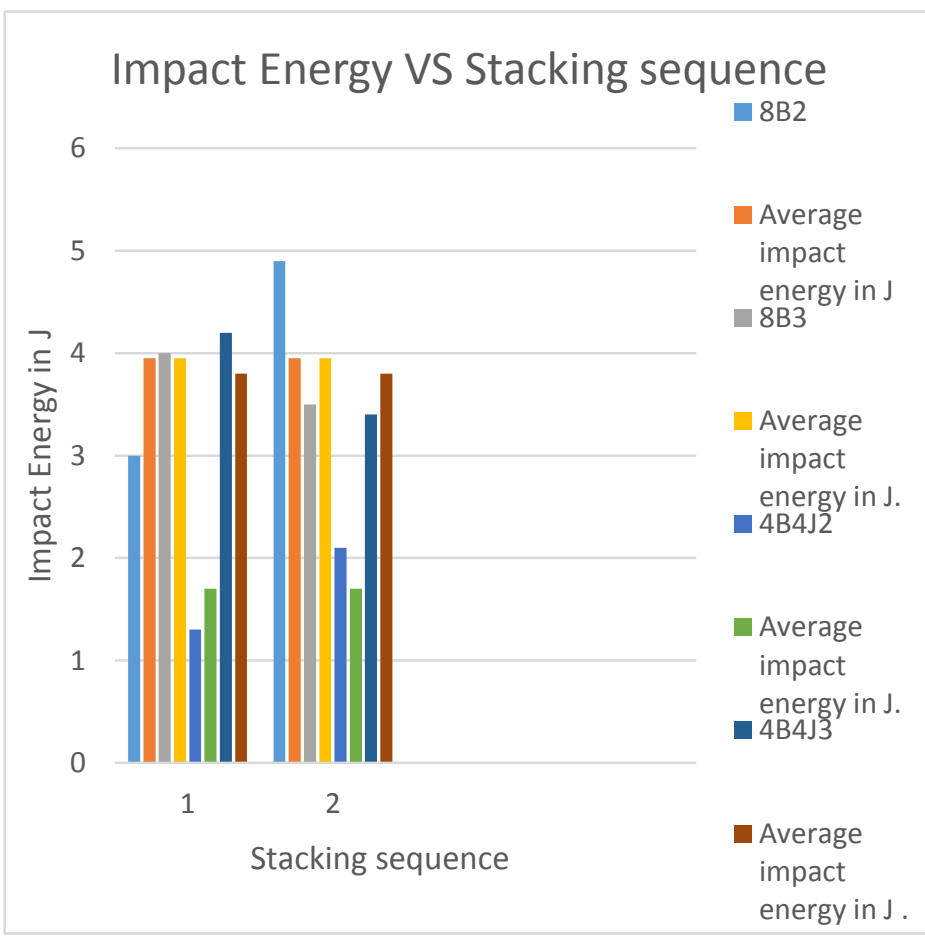

Graph. 1. Bar graph variation stacking sequence versus Impact Energy J.

From the above graph gives the variation in stacking sequence and impact energy the maximum impact energy was found for $4 \mathrm{~B} 4 \mathrm{~J} 3 \mathrm{~mm}$. The impact energy was maximum for $3 \mathrm{~mm}$ basalt and jute hybrid. This is due to variation in stacking sequence and the thickness of the fabricated composites.

\section{CONCLUSION}

From the experimentation of the impact test the following behaviour with respect to stacking sequence is noted and the following conclusions are derived:

1. The main concept is that the variation in impact properties are based on the variation in stacking sequence.

2. The thickness of the given composites with respect to stacking ratio has a greater impact on the impact properties.

3. There might variation in impact properties based on curing temperature during preparation of the composites.

4. The average impact energy was in the good variation with respect to the stacking sequence.

5. Since the fabrication of hybrid composites have good variation with respect to primary mechanical testing the impact testing for the development of hybrid composites are intended to have good behaviour with respect to impact properties. 


\section{International Journal of Engineering Applied Sciences and Technology, 2019 Vol. 4, Issue 4, ISSN No. 2455-2143, Pages 350-354 \\ Published Online August 2019 in IJEAST (http://www.ijeast.com)}

\section{REFERENCE}

[1] Nayan patel, Kudan Patel, Piyush Gohil (2018) Investigation on mechanical strength of hybrid Basalt/Glass composites, IJAER,Vol 13, Number 6 (2018) pp 5083-4088.

[2] K Arun Prasanth (2013) Mechanical properties of woven fabric basalt/jute reinforced polymer hybrid composites, IJMERR, Vol2 October 2013.

[3] M Vijay Kumar, K Niveditha (2017) Comparison of basalt fiber and steel fiber as additives to concrete", IJRASET, Vol 5, August 2017.

[4] Namasivayam Navaranjan (2017) Impact strength of natural fibre composites measured by different test methods: IJMSNT, 2017.

[5] T. Sivasankariah, V. Kalyan Srinivas H. Uma Shankar (2017) Impact characteristics of polymer matrix, IJESRT, Vol.6, February 2017.

[6] V. Fiore, T. Scalici, D. Badagliacco, D. Enea, G. Alaimo, A. Valenza. (2017) Aging resistance of bio-epoxy jute-basalt hybrid composites as novel multilayer structures for cladding. Composite Structures 160 (2017) 1319-1328

[7] B.D.Agarwal., L.J Broutman. (1990) Analysis and Performance of fiber Composites, John Wiley and Sons. Inc. 1990.

[8] C.V. Srinivasa, K.N. Bharath. (2011) Impact and Hardness Properties of Areca Fiber-Epoxy Reinforced Composites. J. Mater. Environ. Sci. 2 (4) (2011) 351-356.

[9] C. Clemons, A. R. Sanadi. (2007) Instrumented Impact Testing of Kenaf Fiber Reinforced Polypropylene Composites: Effects of Temperature and Composition. Journal of Reinforced Plastics and Composites. (2007).

[10] A. Malhotra \& F. J. Guild. (2014) Impact Damage to Composite Laminates: Effect of Impact Location. Appl Compos Mater 21 (2014) 165-177.

[11] Vivek Dhand, Garima Mittal, Kyong Yop Rhee, Soo-Jin Park, David Hui. (2015) A short review on basalt fiber reinforced polymer composites. Composites: Part B 73 (2015) 166-180 [12] Hai Zhang, Stefano Sfarra, Fabrizio Sarasini, Clemente Ibarra-Castanedo, Stefano Perilli, Henrique Fernandes, Yuxia Duan, Jeroen Peeters, Nicolas P. Avdelidis and Xavier Maldague. (2017) Optical and Mechanical Excitation Thermography for Impact Response in Basalt-Carbon Hybrid Fiber-Reinforced Composite Laminates. 1551-3203 (C) 2017 IEEE

[13] Fabrizio Sarasini, Jacopo Tirillò, Marco Valente, Teodoro Valente, Salvatore Cioffi, Salvatore Iannace, Luigi Sorrentino. (2013) Effect of basalt fiber hybridization on the impact behavior under low impact velocity of glass/basalt woven fabric/epoxy resin composites. Composites: Part A 47 (2013) 109-123
[14] E. Elbadry, H. Hamada. (2012) Impact Properties of Natural Jute Fabric/Jute Mat Fiber Reinforced Polymer Matrix Hybrid Composites. Journal of Mechanics Engineering and Automatio, 2 (2012) 381-388.

[15] C. Scarponi, C. S. Pizzinelli, S. Sanchez-Saez, and E. Barbero. (2009) Impact load behaviour of Resin Transfer Moulding (RTM) hemp fibre composite laminates. Journal of Biobased Materials and Bioenergy, 3(3) (2009), 298-310.

[16] Shahzad, A. (2011). Impact and fatigue properties of hemp-glass fiber hybrid bio composites. Journal of Reinforced Plastics and Composites, 30(16), 1389-1398.

[17] Naidu, V. N. P., Reddy, G. R., Kumar, M. A., Reddy, M. M., Khanam, P. N., \& Naidu, S. V. (2011). Compressive \& impact properties of sisal/glass fiber reinforced hybrid composites. International Journal of Fibre and Textile Research, 1(1), 11-14. 